Indonesian Journal of EFL and Linguistics

Vol. 4 No. 2, 2019

eISSN: 2503-4197, pISSN: 2527-5070

www. indonesian-efl-journal.org

\title{
Listening Materials for Vocational High School Students in Indonesia: Teachers' Perception
}

\author{
Sularti \\ Universitas Sebelas Maret, Surakarta, Indonesia \\ e-mail: lrti_art159@yahoo.com \\ Nur Arifah Drajati \\ Universitas Sebelas Maret, Indonesia \\ e-mail: nurarifahdrajati@staff.uns.ac.id \\ Slamet Supriyadi \\ Universitas Sebelas Maret, Indonesia \\ e-mail: pripus.lppmuns@yahoo.co.id
}

\begin{abstract}
:
Initially, communication is set up by listening. Students need the ability of listening skill for educational purposes and prepare themselves in social life. This study had the objective to investigate the perceptions of the teachers about the existing listening materials at the vocational high schools in Indonesia. In this study, the researcher engaged seventeen teachers of vocational high schools in Indonesia to be the participants. Data were collected by distributing a questionnaire then followed by an interview toward two participants. The results showed that listening materials met students' needs, supported by the process of the scientific approach, were appropriate with the objective of the study and students' level of English, related to the syllabus of the 2013 curriculum model included the topic learned. On other hand, listening materials did not improve students' ability in English, monotonous, made students having less focus, difficult to understand, difficult to build students'
\end{abstract}


Sularti, Nur Arifah Drajati and Slamet Supriyadi

prior knowledge, boring, and uninteresting. Finally, as the teachers'view, the use of video could be the solution to the problems.

Keywords: Existing Materials, Listening Skill, Teachers'Perception

\section{INTRODUCTION}

It has been extensively recognized as the influential of materials in language teaching and learning (McGrath, 2013). Various sources of English teaching materials are used as references in teaching and learning activities. The compatibility of English language teaching to the needs of learners determines how efficiently the materials support learners acknowledge their L2 learning goals (Garton \& Graves, 2014; McGrath, 2006; Tomlinson \& Masuhura, 2017). For students who use English as a foreign language, the availability of material with not familiar with the language as they use every day can prevent students from mastering the teaching material.

Given the importance of English in the millennial era, the government has made English language lessons a compulsory subject at the junior and senior high school levels. English subjects included in the 2013 curriculum and government places the importance of the role of English in conveying ideas to foreign countries that have different languages with the language used by students in their daily lives and absorb ideas from the outside for the benefit of the people. Competence of attitudes, knowledge, and skills are competencies that must be mastered by students to equip them to enter the workforce after they graduate. The curriculum for senior high school and vocational high school has the same syllabus in the revised edition 2013 curriculum.

The national curriculum which is changing raises expostulations for English teachers in the process of teaching English. An appropriate lesson plan with the objective of the study, the process of teaching and learning which innovative and significant, and closed by students' assessment to identify the results of the learning are required for the teachers. It is considered that the lesson plan is urgent in case the whole element of the objectives of the study, activities during the learning, and the process of assessing are explained in the curriculum (Ediger, 2002).

The contents of lesson plan require the components of core competencies and basic competencies included in the 2013 curriculum. The components of the core competency are the amount of four supreme such as spiritual and social attitudes, knowledge, and skills. These core competencies then divided into the aspect of affective, aspect of cognitive and aspect of psychomotor (Widodo, 2016: 137). The government policy of the 2013 curriculum implies to apply a scientific approach in the learning process which consists of a sequence of steps that begins with 
observing, questioning, exploring/experimenting, associating, and communicating (Widodo, 2016: 138).

Language skills are required for mastering English. Those are the skill of listening, reading, speaking, and writing. The most crucial to learning the English language and English communication is listening skill (Hamouda, 2013). The skill which most frequently used for people in daily communication is listening (Celce-Murcia, 1995). The frequently of people to listen is equal to twice people speak. Four times people read as same as once people listen. While five times people write is as same as once people listen (Morley, 1991, p. 81). Listening becomes a basic skill that helps to communicate effectively in English for the students (Nunan, 1997, p. 1). Without learning listening, a person will not be able to speak, read, or write. Therefore, students need to master the listening skill in teaching and learning activities. However, a condition in the field, namely in the English language class, reflects the condition that listening skill becomes a skill that is ignored by the teacher to be taught to students.

Listening skills in EFL are considered trivial because of a theory that listening is learned automatically and thoroughly in once (Huei-Chun, 1998). Solak and Altay, and many other researchers call listening skills as "Cinderella skills", which are skills that are neglected by their big sisters called speaking that occurs in language learning. Many people thought that listening was a less important skill and were ignored in classrooms in the EFL. This continued until the end of the 1961s. In the chosen language, both researchers and teachers were more focused on reading skills and the grammar used, while teaching the skill of listening was not received as a substantial feature in the process of language teaching (Richards \& Rodgers, 2001). The insignificance of listening in the language teaching was strengthened by Field's conviction (2008) who states that "in the early days of English Language Teaching (ELT), listening chiefly served as a means of introducing new grammar through model dialogues" (p. 13).

To solve the problem of the obstacles in mastering listening skills, interesting teaching methods are needed to minimize students' boredom when participating in the learning activities. Teaching listening that only uses audio can be one of the obstacles in learning listening skills. Accessing the internet easily makes consideration in generating ideas for displaying videos in listening skill learning. So, students do not just listen to audio when listening to activities, but they can see videos that accompany the content of the audio being played.

Video provides many learning experiences that are beneficial to students. The language used in the video can enrich the language experience for students. Videos can increase students' understanding of other cultural or cultural lists. By watching videos, students' creativity will develop. And the benefits of other videos are that students are increasingly motivated to learn (Harmer, 2007). 
Research on the investigation of students' difficulties in listening had been done before. A study entitled "Analyzing Students' Difficulties toward Listening Comprehension" was dealt with by Darti and Asmawati (2017). The study was to uncover the problems of listening comprehension faced by the students in Indonesia with the subject were 37 students. Data collecting in the form of questionnaire and interview then analyzed using the descriptive method. Some findings from the results of research conducted by Darti and Asmawati are described as follows. Listening lessons are difficult subjects. The difficulty of students in learning to listen is influenced by the subject materials, factors of the listener himself, and physical condition.

Hence, the main difficulty encountered by the students covering how the accent of the speaker, how the speaker pronounce the words, whether the speaker speech fast or not, whether the speaker has sufficient vocabulary or not, the condition of the sounds from the recorder, the students ability to concentrate, and the different accent of the speakers. The teacher gave the solutions of the problems by developing the strategy of learning such as find the sources of listening material and adapt it, improve the quality of the listening materials, built up the students' vocabulary, give the students sources of listening with various accents, invite native speakers to improve the students' pronunciation, set up the students' knowledge to familiar with the topic discussed. The teacher also keeps the students' motivation.

A study on "Prospective EFL Teachers' Perceptions of Listening Comprehension Problems in Turkey" deal by Solak and Altay (2014). The study focuses on the value of listening skill in the environment of English as a foreign language and determine the prospective English teachers' perceptions toward listening comprehension's problems. The participants contributed to this study were 124 prospective English teachers at ELT Department at a state-run University in Turkey. The positive impacts from the finding of this study were participants able to find the main idea from the task given in listening and able to notify the topic they already knew. While the negative impacts from the finding of this study were the students' difficulty in identifying the words with unclear pronunciation and different kinds of accents. Furthermore, the participants who did not know a lot of words delivered became the justification of the disorder of comprehension.

The other study, "Students' Needs Analysis in the Content of Vocational High School English Textbook" by Cahyati (2014), aimed at analyzing students' needs in learning English for four language skill: listening, speaking, reading, and writing and the components of language such as grammar and vocabulary. This study also identified the agreeing between English textbooks used and the students' needs. The setting of the place was in Bandung and Cimahi in which a total seven vocational high schools with the major of Computer and Network (Tehnik Komputer Jaringan, hereafter called TKJ) included at the school. The results of the study showed that the concern of the students toward the learning English was to find out the students' 
professions in the field of academic and the students' needs of the future which related to language skills containing listening, speaking, reading, and writing and some components of the language. While the results of the English textbooks' identification showed that the books still formulated the materials of the study in general rather than focused on the specific area of the TKJ major. Overall, this study could be used as a reference to considering the students' needs of the English materials and the contents of the textbooks which were used by the English teacher in the teaching and learning process.

The following is a review of research on teaching listening using video as the learning material. The study was conducted by Nova (2017) with the research title "Utilizing Video for Technology Integration Support in Indonesian EFL Classroom: Usage and Obstacles". The study was conducted to determine teacher perceptions consisting of benefits and obstacles in the use of video as learning material. The survey research method by distributing purposeful questionnaires was used to collect the data. The results showed positive sides and obstacles to the use of video for listening skills. The positive impacts that arise such as the presenting material in the form of visual and audio, building students 'background knowledge, showing students a variety of language expressions, fostering students' motivation and interest in learning, and ways of learning for students. While the obstacles that arise such as the limited facilities, lack of technical support, difficulty in finding relevant videos, difficulty in video editing, and lack of student concentration when viewing videos while listening to the audio. The results of this study, that is, EFL teachers were recommended to use video to improve teaching and learning in the classroom.

By considering the conditions of learning listening skills mentioned above, the researcher aimed at gathering information on teachers' views of the existing materials for listening skills at vocational high schools in Indonesia. The information was collected by distributing questionnaires to seventeen teachers at vocational high schools in Indonesia. Data was also obtained by conducting interviews with the participants.

\section{LITERATURE REVIEW}

Listening is defined as the identification of the component of text: gist, main idea, supporting points, and even conclusion in which the understanding toward the given input represented (Brown, 2004). Students will have more chance to interpret the conversation by listening to the input messages and comprehend the messages properly.

Listening is admitting sending pictures, views, ideas, beliefs, manners of behavior, and feelings from the utterer (Rost, 2011, p. 3). Listening does not merely hear messages through the hearing instrument. Visual media support the messages that comprise meaning delivered by the speaker that is seen when someone listening becomes a supporting component of the success of the listening process. 
Rost (1991) opines the term of listening as a process which is conducted actively. Listeners have to think in an active way to be better listeners when they do listening. Furthermore, listening acts as a part of language learning which have an active feature. Listening is used in learning of language with a lot of activities, both in the classroom and out of the class. Listening skill becomes the principle to make sense to the other language skills develop. The awareness of teachers on the links of listening skill to the other ones and their consistency to point out the links to the learners may lead the learners to develop their language thoroughly. A teacher plays a role as a researcher who conducts the listening development actively. The teacher suggested be active in planning, preparing, giving feedback to the class activities and investigate the way their listening skills are altering and increasing (Rost, 1991, p. 3).

Listening skill for Vocational High School is assorted from the Senior High School since the Vocational High School provides the students to be ready in a professional career in accordance to their chosen major based on their interest and aptitude. The term of an umbrella for various disciplines of English language teaching is delivered to the English for specific purposes (Vogt \& Kantelinen, 2012). Furthermore, English in Vocational High School that considered as English as a foreign language commonly designed to comprehend a confined variety of English. The specific area of study later becomes linguistically well-known with the term "English for Specific Purposes (ESP)." Hutchinson \& Waters (1989) show that the approach to ESP is suggested related to the precepts of effective teaching learning the language for general purports. They add that the concern of teaching ESP in the past is on the factors of linguistic in the language. But now, it has alternated on developing the skills of communication. Learning is mainly directed by the specific learners' needs for comprehending the language. It is in line with the definition of ESP which also stated by them; ESP is a teaching language using an approach that for the content and methods applied are based on students' needs. (Hutchinson \& Waters, 1989). Moreover, Steven in Munby (1981), reminds us that there are two main aspects in ESP, the first is study, and the other one is occupation. The aspects of ESP are very important in teaching especially for preparing teaching materials, where knowledge, basics of teaching, teaching practices, and training are acknowledged and where it is the cognition to function in English, which is to be practiced.

Thus, to fill the materials that students' need, the government through its regulation design the curriculum for the planning, executing, and controlling on the system of rules of education. The curriculum always changes as the change of several factors influenced it. The current curriculum applied in Indonesia is the 2013 curriculum.

Video may become the alternative tool that is beneficial for acquisition the language. There are several definitions of video. The definition of a video as stated by Wilson (2000), it is a context of audio-visual which containing of the selected messages and be displayed in a sequence way context (Wilson, 2000). 
In teaching English listening as a foreign language, information conveyed visually in the form of video is important. Rubin in Buck (2001, p. 47) argues that in learning languages, visual support can help students who have low ability and can also help them to understand more complicated text. Movements, actions, moods or emotions, setting, etc. that can be observed by students in the video, have an important effect in encouraging visual desire to practice the language. An authentic speech is a speech delivered without any purpose to be used in the teaching field. The speech is the result of the speech of a native speaker or competent speaker in English (Harmer, 2001, p. 134 - 135) also make the students interested in.

Using video material in classroom learning has its benefits. The advantages are 1) motion; the movements seen in the video help students master psycho motor skills, 2) processes; helping students to understand the order in which things work effectively, 3) dramatically; able to re-inspire student experience, 4) learning skills; helping students to master repeated observations and practices, 5) affective learning; videos are useful for the formation of personal and social attitudes, and 6) cultural understanding; by looking at daily activities from various spheres of the region, can enhance the development of appreciation for other cultures.

Moreover, when video is used in learning activity, special dimensions and additional dimensions can be increased in the learning experience. Those are: Students not only listen but can see and interpret the meaning of the listening text, enrich knowledge and awareness of other cultures, create memorable and interesting video results, and increase interest in understanding and learning the material (Harmer, 2007, p. 281).

\section{RESEARCH METHODOLOGY}

\subsection{Research Method}

This survey research was used to reveal the questions proposed in this research. A survey is a method which is usually applied in the field of the social sciences to realize social phenomena, and the phenomena of the societies in working, and also to attempt theories of behavior (Groves, Fowler, Couper, Lepkowski, Singer, and Tourangean, 2004a, p.2). This method was used to find out the teachers' view of the quality of existing materials of listening skill in this research.

\subsection{Research Participants}

The target population of this research was in-service teachers of Vocational High School in Indonesia. Seventeen teachers were participating in this research. Here, the researcher then selects two teachers to invite an interview concerning the information of the questionnaire they already filled. Those seventeen participants consisted of twelve females and five males. 


\subsection{Research Instrument}

To collect the data for this research, distributing questionnaire and interviewing the participants were conducted the method proposed by Groves et al. (2004b, p. 3). Besides, Trochim (2006) states that in survey research, the researcher can also distribute a questionnaire. Based on the theories explained above, the researcher used two instruments to gather the data; those were questionnaire and interview.

The first instrument was a questionnaire. Based on Seliger and Shohamy (1989, p. 172) a questionnaire is a data collection in the form of printed materials which include questions or statements to answer by the subjects the research. This questionnaire was used to investigate the students' view on the quality of existing listening materials. There were eighteen numbers of statements with Guttman scaling containing "yes" or "no" answer. This scale was developed by Louis Guttman (1944, 1950). Participants might write additional information of their choice in the available column.

The second instrument was an interview. It was taken from the questionnaire with several additional questions related to the questionnaire. The using of interview was conducted to fortify the answers on the questionnaire chosen by the interviewee. According to Kvale in Cohen, Manion, and Morrison (2000, p. 267), "the use of interview in research marks a move away from seeing human subjects as simply manipulable and data as somehow external to individuals, and towards regarding knowledge as generated between humans, often through conversations." In this research, the researcher used a structured interview. The structured interview is a variation of the employment interview designed to reduce the effect of different biasing elements on interview qualifying by limiting "the degree of discretion that an interviewer is allowed in conducting the interview" (Huffcut \& Arthur, 1994, p. 186). The researcher prepared in advanced the questions would be delivered to the interviewee.

\subsection{Data Collection Technique}

The researcher collected data from the participants by using a questionnaire. The aim of this observation was to know the materials used recently. The questionnaire was distributed to in-service teachers through Google forms while the interview was used to reaffirm and dig more information about in-service teachers' view on the quality of existing materials for listening skill.

\subsection{Research Procedures}

There were some procedures that the researcher took in conducting this research. Looking at the issues in the worlds, specify them, and finally formulate the problem, the researcher chose the problem to be solved. The researcher then decided where the setting of the place and its participants. Then the researcher communicated with 
the English teacher to have a schedule when the appropriate time would be given to take the data needed.

The researcher then shared the questionnaire in the form of Google form and interviewed some in-service teachers for the next occasion, analyzed the obtaining data, interpreted the data, made a conclusion, and finally reported the result of the research.

\subsection{Data Analysis Techniques}

The collecting data then proceed. The data of the questionnaire and interview were being analyzed to find the answers of the questions mentioned in the research. The data were analyzed descriptively by using the interactive model of Miles and Hubberman.

\section{FINDINGS}

Teachers' perceptions of listening skill materials which exist in vocational high school were reported in the table 1.

Table: 1 the existing materials for listening skill

\begin{tabular}{lcc}
\hline \multicolumn{1}{c}{ Items } & f & $\%$ \\
\hline $\begin{array}{l}\text { 11.Listening materials are not appropriate with the context of } \\
\text { students' daily life. }\end{array}$ & 8 & 47.1 \\
$\begin{array}{l}\text { 5.Listening materials meet students' needs (related to their } \\
\text { major). }\end{array}$ & 10 & 58.8 \\
$\begin{array}{l}\text { 7.Listening materials still do not improve students' ability in } \\
\text { English. }\end{array}$ & 10 & 58.8 \\
$\begin{array}{l}\text { 10.Activity and materials of listening are monotonous. } \\
\text { 4.Listening materials are supported by the scientific } \\
\text { approach in the process of study as being suggested in the }\end{array}$ & 10 & 58.8 \\
$\begin{array}{l}\text { 2013 curriculum. } \\
\begin{array}{l}\text { 8.Listening materials using audio-only make students having } \\
\text { less focus on the materials. }\end{array}\end{array}$ & 12 & 70.6 \\
$\begin{array}{l}\text { 12.Listening materials using audio-only are difficult to be } \\
\text { understood. }\end{array}$ & 12 & 70.6 \\
$\begin{array}{l}\text { 9.Listening materials using audio-only make students still } \\
\text { having difficulties to build their prior knowledge. }\end{array}$ & 14 & 82.4 \\
$\begin{array}{l}\text { 13.Listening materials using audio-only make students } \\
\text { bored. }\end{array}$ & 14 & 82.4 \\
$\begin{array}{l}\text { 2.Listening materials are suitable for the objective of the } \\
\text { study. }\end{array}$ & 15 & 88.2 \\
$\begin{array}{l}\text { 6.Listening materials are appropriate with English students' } \\
\text { level. }\end{array}$ & 15 & 88.2 \\
\hline
\end{tabular}

Indonesian Journal of EFL and Linguistics, 4(2), 2019 
Sularti, Nur Arifah Drajati and Slamet Supriyadi

\begin{tabular}{lccc}
\hline $\begin{array}{l}\text { 1.Listening materials are related to the syllabus of the 2013 } \\
\text { curriculum model. }\end{array}$ & 16 & 94.1 \\
$\begin{array}{l}\text { 3.Listening materials are suitable for the topic learned for } \\
\text { students in vocational high school. }\end{array}$ & 16 & 94.1 \\
$\begin{array}{l}\text { 14.Listening materials using audio-only are not interesting. } \\
\begin{array}{l}\text { 15.Listening materials will be interesting when using video. } \\
\text {. }\end{array}\end{array}$ & 16 & 94.1 \\
\end{tabular}

The explanation of the findings was presented by displaying data from the lowest percentage of the agreement of the participants toward the items in the questionnaire. The finding showed that participants agreed with item 11 explaining listening materials are not appropriate with the context of students' daily life. That was $47.1 \%$ of 17 participants. The next agreed item, $58.8 \%$ were three items: the item 5 saying listening materials meet students' needs (related to their major), item 7 saying listening materials still do not improve students' ability in English, and item 10 saying activity and materials of listening are monotonous. Following these, the percentage of agreed which came in a sum of $70.6 \%$ were happened in items 4,8 and 12 saying listening materials are supported by the scientific approach in the process of study as being suggested in the 2013 curriculum, listening materials using audio-only make students having less focus on the materials, and listening materials using audio-only are difficult to be understood. Next, item 9 and 13 came with a sum of $82.4 \%$ citing listening materials using audio-only make students still having difficulties in building their prior knowledge and listening materials using audioonly make students bored. The following agreed item with the higher mean, $88.2 \%$, were the items 2 and 6. Item 2 explaining listening materials are suitable for the objective of the study. Item 6 saying listening materials are appropriate with English students' level. Participants mostly allowed with item 1 declaring listening materials are related to the syllabus of the 2013 curriculum model. This item has a sum of $94.1 \%$. The percentage of the item, $94.1 \%$, were also happened to the two other items. Those were item 3 and item 14. Item 3 saying listening materials are suitable for the topic learned for students in vocational high school. Item 14 saying listening materials using audio-only are not interesting. Finally, all participants agreed with item 15 explaining listening materials will be interesting when using video. Those were $100 \%$ of 17 participants.

Overall, the data of the questionnaire is presented in the form of the figure 1 below. 


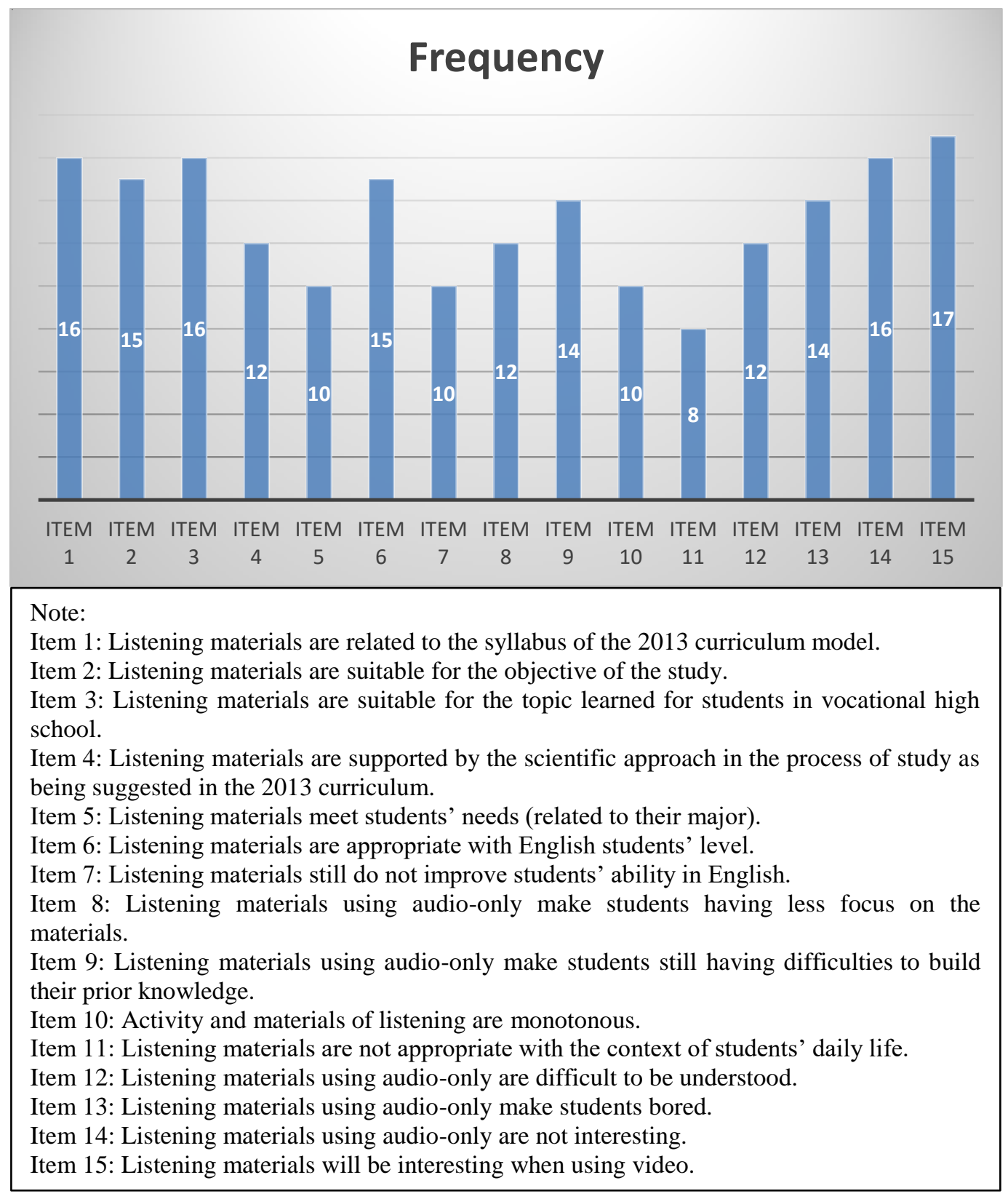

Figure 1. The existing materials for listening skill

Data from the questionnaire were then supported by reconfirming to two participants through an interview. Several items in the questionnaire were delivered to the participants to get a more detailed explanation. For the question of whether listening materials supported by the scientific approach in the process of study as being suggested in the 2013 curriculum, participants 1 (hereafter P1) explained: 
"Listening can be taught started from listening to videos, and listening tasks can be taught in the process of associating and listen also sharpened when the process of communicating, for example, there are presentations of other students then the students are suggested to understand the meaning of the presentation content."

The explanation also came from the participants 2 (hereafter P2) for the question of whether listening materials supported by the scientific approach in the process of study as being suggested in the 2013 curriculum, P2 explained:

"I agree that the listening material can be used for K13. I use the listening section for a variety of basic competencies, and in my opinion, English requires listening files or materials that we use for students to copy or imitate. My students have an English beginner level. They must learn from intonation, pronunciation by the rules of the correct pronunciation. Then I proceed to their creative process to develop their writing and speaking competencies after they get listening materials."

The next question was whether listening materials are appropriate with the context of students' daily life. $\mathrm{P} 1$ responded that

"Listening to the material presented by the teacher can be very contextual eg., KD analytical exposition can be given listening to the discussion of dialogue about social media, corruption, etc. And almost all KD in English can be contextually adjusted and must be in accordance with K13."

For the same question, whether listening materials are not appropriate with the context of students' daily life, P2 answered:

" I found some of my students after I introduced pronunciation through listening media, they have more self-confidence when saying congratulation, compliment such as wow, that's great! They are indirectly aware and understand when and where they can say those words, to whom they say it. It is not yet significant, but I noticed that the small change I noticed and I was quite proud of the success of my children to be able to use correct short responses when answering questions from me."

The following question in the interview, how about the listening materials, was replied by $\mathrm{P} 1$ that listening materials could vary and its text also could be designed in varied. While P2 gave a more detailed explanation as follow:

"I realize that the students I deal with are diverse. Intellectual intelligence that they have also varied. The level of their interest in something will also vary. When I play listening material so long, I will 
see students' who are discouraged, easily bored, and finally, auto does not focus on listening material that I submit. For example, I play a song for the opening of my lesson, where I ask to focus and fill in the blank. There are words they have to put on the missing song, fill missing lyric. For the first turn around, they felt very enthusiastic. They feel confident they can do their job. But after they read long writing, they began to doubt what words they heard, and they began to feel disappointed, they began to feel insecure. The same thing happened when I played it again. Some children are no longer interested in listening to files for the album that I play. A different thing happens when I play the listening file, which is a hotel reservation dialog where once again, the children are asked to fill in the blank words according to the reservation. Then the second time I play the video. Then from there, the children can cope with being able to get more information from the video clips that I play, from facial expressions, from receptionist actions. And they were finally able to find the right answer from the assignment I gave. My conclusion, listening to material files must vary a lot how to convey it well to students. Teachers must use top-down or down-top techniques as the initial basis for how they must intersect with sentences that they have not previously looked at or have never been familiar with in English. R: Does the listening material not fit the context of their daily lives?"

\section{DISCUSSION}

The availability of the materials at a certain school has a great impact toward the students' proficiency of the subject materials. In daily life, English language is mostly used by the people in their activities. The materials given to the students when they learn English are appropriate with the context of the students (based on the students' major). This condition makes the students easier to understand the materials given.

Teachers taught listening skill based on the 2013 curriculum including the objective, topic materials, and the process of learning which used scientific approaches that recommended by the government. Students got the lesson which appropriate with the curriculum of 2013. As the theory that a school which implementing ESP, in regulating the contents of the material and methods used in teaching approach is based on the learning objectives of the students (Hutchinson \& Waters, 1989), students need materials which related to their program. Furthermore, according to Inayah (2017), the goals of teaching in vocational school are to develop their skills which they needs related to a particular job. Therefore, listening materials were appropriate to the students' major. As the vocational high school students, they should learn English specifically for their program. They need to prepare themselves in the workplace especially in communication with their relations. It was a good 
finding that the curriculum as a mean to achieve educational goals used by the teacher as a basis for learning activities.

On the other hand, participants realized that there was still many weaknesses that should be improved to be better by the educational environment to achieve learning goals. The weaknesses of the existing listening materials were found in the several occasions. There were no listening materials in the 2013 Curriculum textbook for Senior High School and Vocational High School published by the Minister of Education and Culture. So, teacher used other book sources or found the listening materials from the internet. The other finding stated that more than fifty percentage of the participants agreed that listening materials still did not improve students' ability in English. It could be as the effect of the monotonous of the activities during the class. Participants agreed that the activities and materials in learning listening are monotonous. Brown (2007) suggested that is necessary to carry out various tasks during listening activity to give them opportunities to get lots of experience with different types of listening materials. The monotonous could make students feel bored. Students tend to be reluctant to learn listening materials which gave the resulting in the assumption that listening is a difficult subject. Meanwhile, participants stated that listening materials were not interesting. Listening materials provided to students can influence student learning conditions including student motivation to learn can increase, and the willingness to study seriously and focus on activities in listening learning. The materials for learning which are newsworthy able to change students' interest better (Rowntree, 1997). It becomes consideration for teacher creates the activity in listening class more interesting so that students have interest to learn.

Interesting materials can attract students to give more attentions toward the learning process. The focus of listening which most schools apply by using audio only become the factor of the weaknesses of the listening materials.

As the growing of technology in all aspects of life including the aspects of education, the utilization of audio as the learning materials in the instructional process for learning listening skills seems rather inefficient (Chen et al., 2014). Participants proved that listening materials by using audio only make students less focus on the materials. Listening materials by using audio make students had a difficulty to build their mind to imagine the activities which happened in the materials and topic which was discussed. They tend to listen in low understanding of their listening. Furthermore, listening materials are not followed by video one. As stated in the previous questionnaire item that audio only did not enough to make students easily understand the contents of the materials. A theory from Harmer (2007) claimed that listening materials will be interesting when followed by video. The students' interest raises as they can see and in the same time they can also hear the language in use by the speakers then it results their improvement in motivation (Harmer, 2001). Mirvan (2013) proposes that students' motivation improve when 
they learn using video materials since the content of the video can bring out them to the diverse situations in wide range in which they can perceive their experience in the concrete life situations. This statement agreed by the P1 who gave the opinion in her interview, "Listening can be taught started from listening to videos, ...." Furthermore, at the next interview, she added:

"Then the second time I play the video. Then from there, the children can cope with being able to get more information from the video clips that I play, from facial expressions, from receptionist actions. And they were finally able to find the right answer from the assignment I gave."

Students were helped in understanding listening materials when supported by video. They got information through the expressions of the face showed in the video and the acting of the person which became the participant in the video. These finding are related to the theory from Smaldino (2002). As stated in the result from the participants' view that all of them proved that video makes listening materials more interesting.

\section{CONCLUSION}

Good planning of learning and the availability of materials that fit the needs of students will support the achievement of the objective of the learning. The following points support the learning process of students. Listening materials meet students' needs (related to their major). Listening materials are supported by the scientific approach in the process of study as being suggested in the 2013 curriculum. Listening materials are suitable for the objective of the study. Listening materials are appropriate with English students' level. Listening materials are related to the syllabus of the 2013 curriculum model. Listening materials are suitable for the topic learned in the vocational high school.

While the points need to be given a solution are on the problem of listening materials that do not support students to understand and master the materials well. Listening materials still do not improve students' ability in English. The activity and materials of listening are monotonous. Listening materials using audio-only make students having less focus on the materials. Listening materials using audio-only are difficult to be understood. Listening materials using audio-only make students still having difficulties in building their prior knowledge. Listening materials using audio-only make students bored. Listening materials using audio-only are not interesting.

Overall, participants agreed that difficulties in learning listening skills become obstacles for students to master English, especially listening skill, well. It should be new materials which meet students' needs. As agreed by all participants in this research, the integration of interesting video materials could become the solution to improve students' ability in listening skill. 
Sularti, Nur Arifah Drajati and Slamet Supriyadi

Acknowledgements: The researcher deeply to thank teachers and all who have promoted to implementing this project to be done. The researcher also gives special honor thanks to the Endowment Fund for Education (LPDP RI) who is being a sponsor giving a chance to the researcher to conduct the research.

\section{REFERENCES}

Brown, H. D. (2004). Language assessment: principle and classroom practices. New York: Pearson Education.

Brown, H. D. (2007). Teaching by principles: an interactive approach to language pedagogy. New York: White Plains, NY: Longman.

Buck, G. (2001). Assessing listening. Cambridge: Cambridge University Press.

Cahyati, S.S. (2014). Students' needs analysis in the content of vocational high school English textbook. Journal Ilmiah Stikip Siliwangi Bandung, Vol. 8(1), 29-39.

Celce-Murcia, M. (1995). The elaboration of sociolinguistics competence: implications for teacher education. Washington: George Town University.

Cohen, L., L. Manion., K. Morrison. (2000). Research methods in education. London: Routled Falmer.

Darti \& Asmawati (2017). Analyzing students' difficulties toward listening comprehension . ETERNAL (English, Teaching, Learning, and Research Journal), 3(02), 211-228.

Ediger, M. (2002). Psychological lesson plans and units in reading. Eric Journal, 4(41), 1-17.

Field, J. (2008). Listening in the language classroom. United Kingdom: Cambridge University Press.

Garton, S., \& Graves, K. (Eds.). (2014). International perspectives on materials in ELT. Basingstoke: Palgrave Macmillan. https://doi.org/10.1057/9781137023315

Groves, Robert M., F. J. Fowler Jr., M. P. Couper, J. M. Lepkowski, E. Singer, R. Tourangean. (2004). Survey methodology. Wiley-Interscience.

Guttman, L.A. (1944). A Basic for Scaling Qualitative Data. American Sociological Review, 9(2). 139-150. http://dx.doi.org/10.2307/2086306

Guttman, L.A. (1950). The Basis fr Scalogram Analyse. In Stouffer, S.A., Guttman, L.A., \& Schuman, E.A. Measurement and Prediction. Volume 4 of Studies in Social Psychology in World War II. Princeton: Princeton University Press.

Hamouda, A. (2013). An investigation of listening comprehension problems encountered by Saudi students in the EL listening classroom. International Journal of Academic Research in Progressive Education And Development. 2(2), 113-155.

Harmer, J. (2001). The practice of English language teaching. Essex: Longman. Harmer, Jeremy. (2007). How to teach English. Harlow: Pearson Education Limited. 
Huei-Chun, T. (1998). A study of EFL listening comprehension strategies. Eric Journal, 1-19.

Hutchinson, T., \& Waters, A. (1989). English for specific purposes: approaches and methods. Cambridge: Cambridge University Press.

Huffcut, A.I., \& Arthur, W. (1994). Hunter and Hunter (1984) Revisited: Interview Validity for Entry-Level Jobs. Journal of Applied Psychology, 79(2). 184-190. http://dx.doi.org/10.1037/0021-9010.79.2.184

Inayah, N.(2012). EFL teachers' teaching strategies in public vocational high schools in Singaraja. Retrieved on December 25th 2016 http://download.portalgaruda.org/

McGrath. (2006). Teachers' and learners' images for course books. ELT Journal, 60(02), 171-180. https://doi.org/10.1093/elt/cci104

McGrath. (2013). Teaching materials and the roles of EFL/ESL Teachers: practice and theory. London: Bloomsbury.

Mirvan, X. (2013). The advantages of using films to enhance student's reading skills in the EFL classroom. Journal of Education and Practice, 4(13), 62-66.

Morley, J. (1991). Listening comprehension in second/foreign language instruction. Boston, MA: Heinle \& Heinle.

Munby, J. (1981). Communicative syllabus design. Cambridge: Cambridge University Press.

Nova, M. (2017). Utilizing video for technology integration support in Indonesia EFL classroom: Usages and Obstacles. Indonesian Journal of EFL and Linguistics, Vol. 2(1), 15-28.

Nunan, D. (1997). Approaches to teaching listening in the language classroom. Technology in education: communicating beyond traditional networks. Korea TESOL Conference.

Richards, J. C. \& Rodgers, T. S. (2001). Approaches and methods in language teaching. Cambridge: Cambridge University Press.

Rowntree, D. (1997). Making materials-based learning work. London: Kagan Page.

Rost, M. (1991). Listening in action. Prentice Hall: Pearson.

Rost, M. (2011). Teaching and researching listening (2nd ed.). London: Longman.

Seliger, H. W., E. Shohamy. (1989). Second language research methods. Oxford: Oxford University.

Solak, E., \& Altay, F. (2014). Prospective EFL teachers' perceptions of listening comprehension problems in Turkey. Journal of International Social Research, 7(30), 190-198.

Tomlinson, B., \& Masuhara, H. (2017). A complete guide to the theory and practice of materials development for language learning. Chichester: Wiley Blackwell.

Trochim, W. M. K. (2006). Research methods knowledge base. UK.

Vogt, K., \& Kantelinen, R. (2012). Vocationally oriented language learning revisited. ELT journal, 67(1). 62-69. 
Sularti, Nur Arifah Drajati and Slamet Supriyadi

Widodo, H.P. (2016). Language policy in practice: reframing the English language curriculum. English Language Education Policy in Asia, 1(11), 127-151. https://doi.org/10.1007/978-3-319-22464-0

Wilson, C. (2000). Practical aspects of using video in the foreign language classroom. The Internet TESL Journal, 6(11). 